\title{
Reproductive biology and diet of Mustelus punctulatus (Risso, 1826) (Chondrichthyes: Triakidae) from the Gulf of Gabès, central Mediterranean Sea
}

\author{
BECHIR SAÏDI ${ }^{1}$, MOHAMED NEJMEDDINE BRADAÏ ${ }^{1}$ \\ and ABDERRAHMAN BOUAÏN ${ }^{2}$ \\ ${ }^{1}$ Institut National des Sciences et Technologies de la Mer, Centre de Sfax, B.P. 1035, Sfax 3018, Tunisie. \\ E-mail: bechirinstm@yahoo.fr \\ ${ }^{2}$ Faculté des Sciences de Sfax, B.P. 802, Sfax 3028, Tunisie.
}

\begin{abstract}
SUMMARY: Specimens of Mustelus punctulatus were collected between January 2002 and December 2005 from commercial fisheries in the Gulf of Gabès (central Mediterranean Sea). Males and females reached a maximum total length (TL) of 111 and $122 \mathrm{~cm}$ respectively. Males matured between 76 and $88.5 \mathrm{~cm}$ TL, with a size at maturity $\left(\mathrm{TL}_{50}\right)$ of $81.4 \mathrm{~cm}$ TL. Females matured between 88 and $100 \mathrm{~cm}$ TL with a TL $\mathrm{TL}_{50}$ of $95.6 \mathrm{~cm}$. Females had an annual reproductive cycle. Mating occurred through late-May and June. Ovulation occurred from early July to mid-August with parturition occurring from mid-May to early June, after a gestation period of 11 months. The size at birth was estimated to be 24.5 to $30.5 \mathrm{~cm}$ TL. Positive linear relationships were detected between the TL of mature females and ovarian and uterine fecundities. Mustelus punctulatus is an opportunistic predator that consumes a wide range of demersal and benthic prey items. It preys mainly on crustaceans, teleosts and molluscs. Polychaetes, sipunculids, echinoderms and tunicates are also consumed. The species change their main food item as they grow, from crustaceans to teleosts then to molluscs.
\end{abstract}

Keywords: Mustelus punctulatus, reproduction, feeding habits, elasmobranchs, Mediterranean.

RESUMEN: Biología Reproductiva de Mustelus punctulatus (Risso, i 826) (CONdRictios: Triakidae) Del Golfo De Gabès, Mediterráneo Central. - Entre enero de 2002 y diciembre de 2005 se recolectaron ejemplares de Mustelus punctulatus, a partir de las pesquerías comerciales del Golfo de Gabès (Mediterráneo central). Los machos y las hembras alcanzaron una longitud total (LT) de 111 y $122 \mathrm{~cm}$, respectivamente. Los machos maduran entre 76 y $88.5 \mathrm{~cm}$ LT, con una talla de primera madurez $\left(\mathrm{LT}_{50}\right)$ de $81.4 \mathrm{~cm}$. Las hembras maduran entre 88 y $100 \mathrm{~cm}$ de LT, con una LT $\mathrm{LT}_{50}$ de $95.6 \mathrm{~cm}$. Las hembras tuvieron un ciclo reproductivo anual. El apareamiento tiene lugar desde finales de mayo y a lo largo de junio. La ovulación ocurre desde principios de julio hasta mediados de agosto y el parto desde mitad de mayo hasta principios de junio, después de un periodo de gestación de 11 meses. La talla de nacimiento se estimó en 24.5-30.5 cm LT. Se detectó una relación lineal positiva entre la LT de las hembras maduras y la fecundidad ovárica y uterina. Mustelus punctulatus es un depredador oportunista, que consume un amplio rango de presas bentónicas y demersales. Se alimenta principalmente de crustáceos, teleósteos y moluscos. También consume poliquetos, sipuncúlidos, equinodermos y tunicados. Al crecer, la especie cambia su principal alimento, de crustáceos a teleósteos y posteriormente, moluscos.

Palabras clave: Mustelus punctulatus, reproducción, hábitos alimentarios, elasmobranquios, Mediterráneo.

\section{INTRODUCTION}

Three smooth-hound shark species (Chondrichthyes, Triakidae) are present in the Mediterranean
Sea: Mustelus mustelus, M. punctulatus and $M$. asterias (Serena, 2005). Little is known about the distribution of the blackspotted smooth-hound, $M$. punctulatus, because this species are often confused 
with the common smooth-hound, M. mustelus. It is probably limited to the eastern North Atlantic and the Mediterranean Sea (Compagno, 1984). The blackspotted smooth-hound is common along Tunisian coasts, mainly in the Gulf of Gabès (Central Mediterranean Sea) where it forms an important component of the multi-species catch of commercial fisheries (Bradaï et al., 2002).

Despite increasing fishing pressure, there is limited biological information available on $M$. punctulatus. In fact, in the recent IUCN Red List assessments for chondrichthyans in the Mediterranean, this species was not evaluated because the available information was considered deficient (Cavanagh and Gibson, 2007). What is known in the Mediterranean Sea about its reproduction and diet is limited to data concerning $M$. mediterraneus off the Gulf of Tunis (Capapé and Quignard, 1977a,b), which is considered to be synonymous of $M$. punctulatus (Compagno, 1984). Jardas et al. (2007) provided data on the diet composition of $M$. punctulatus in the Adriatic Sea. Limited information on the reproductive biology of $M$. mediterraneus was also reported from off the Senegalese coasts (Capapé et al., 1996).

Knowledge of the reproduction and development of elasmobranch fish is crucial for developing responsible management strategies. Therefore, given the need for critical life history data and the paucity of information, this study provides an opportunity for extending the knowledge of the reproductive biology and diet of this little-studied species by investigating the size at maturity, size at birth, fecundity, reproductive cycles and feeding ecology in the coastal waters of the south central Mediterranean Sea.

\section{MATERIALS AND METHODS}

\section{Sample collection}

Blackspotted smooth-hound sharks were caught by bottom trawl, longline and demersal gill-nets off the Gulf of Gabès coasts from January 2002 to December 2005, at depths between 10 and $100 \mathrm{~m}$, generally on sandy bottoms, occasionally on muddy or detritic bottoms (Fig. 1).

Specimens were sexed and the total length (TL) measured to the nearest centimetre according to Compagno (1984). The total body mass (TM) of each individual was determined to the nearest $10 \mathrm{~g}$.

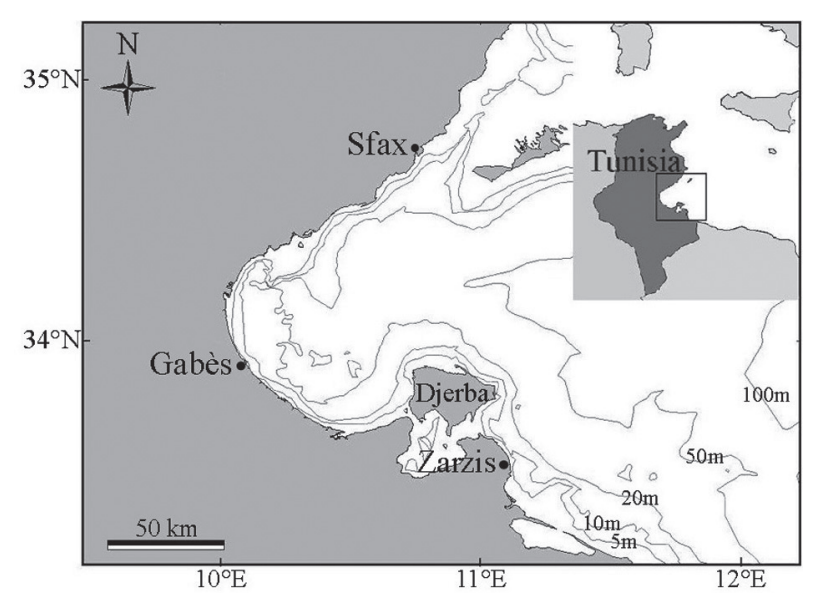

FIg. 1. - Map of the Gulf of Gabès (Tunisia, Central Mediterranean Sea).

Clasper length was measured as the distance from the clasper tip to the pelvic girdle (Collenot, 1969). The TL and TM relationships were calculated separately for each sex.

\section{Reproductive analyses}

Males' reproductive tracts were inspected to determine the condition of the ductus deferens, seminal vesicles, testes and clasper calcification. Testes were excised from the epigonal organ and weighed to the nearest $0.1 \mathrm{~g}$. The gonadosomatic index (GSI), given by the formula [(gonad mass/ total body mass) $\times 100$ ], was used as an indicator of the reproductive cycle for males. The condition of the ovary, oviducal glands and uteri of females was inspected to investigate the number of mature ovarian follicles, the embryo sex ratio, litter size, embryo development, and maturity condition. The diameters of the five largest follicles in the ovary were measured with a caliper to the nearest $0.1 \mathrm{~mm}$. Mean largest follicle diameter (LFD) and mean embryo length by month were compared to determine the periodicity of the female reproductive cycle. Embryo zero length was assigned to the eggs in utero. Only GSI and LFD values respectively of mature males and females were considered. The size at birth was determined by comparing the size of embryos close to the time of parturition with the smallest caught free-living animals.

Maturity stages were determined following a scale proposed by Stehmann (2002) and modified for this species. Males were sorted into three categories: immature (short, soft claspers, threadlike testes, straight ductus deferens); maturing (partially calcified claspers extending beyond the pelvic fins, enlarged 
testes, ductus deferens starting to coil) and mature (long, fully calcified claspers, enlarged testes, ductus deferens tightly coiled). Females were considered immature when they had thin, membrane-like uteri with inconspicuous oviducal glands and an ovary with indistinguishable ovarian follicles. Maturing females had enlarged ovaries, white ovarian follicles of several sizes and partly distended uteri. Mature females had widened uteri with or without visible eggs or embryos and vitellogenic ovarian follicles. The percentage of mature individuals in $2 \mathrm{~cm}$ intervals was calculated for both sexes. A logistic ogive was fitted to the data in order to estimate the size at which $50 \%$ of individuals were sexually mature.

\section{Feeding analyses}

Stomach contents were examined as soon as possible after capture. Preys were identified to the lowest possible taxon. The excess liquid was drained off and the remaining mass of the wet prey was determined to the nearest $0.1 \mathrm{~g}$. The importance of prey was evaluated using the percentage frequency of occurrence $(\% \mathrm{~F})$, the percentage by number $(\% \mathrm{~N})$ and the percentage by wet mass $(\% \mathrm{M})$. We used these values to calculate the index of relative importance (IRI): IRI $=\% \mathrm{~F} *(\% \mathrm{~N}+\% \mathrm{M})($ Pinkas et al., 1971). The IRI values were converted to a percentage following Cortès (1997): \%IRIi = 100 IRIi / $\sum$ IRIi.

Four arbitrarily chosen size classes of M. punctulatus were selected to assess a possible change in the diet with respect to length: young: $\mathrm{TL}<50 \mathrm{~cm}$; small: 50 $\leq \mathrm{TL}<70$; medium: $70 \leq \mathrm{TL}<90$ and large: $\mathrm{TL} \geq 90$. Dietary overlap between groups was determined using the Simplified Morisita Index $\left(\mathrm{C}_{\mathrm{H}}\right)$ (Krebs, 1989):

$$
\mathrm{C}_{\mathrm{H}}=2\left(\sum p_{i j} p_{i k}\right) /\left(\sum p_{i j}^{2}+\sum p_{i k}^{2}\right)
$$

where $p_{i j}$ is the proportion of prey category $i$ (based on $\%$ IRI) used by size class $j$, and $p_{i k}$ is the proportion of prey category $i$ used by size class $k$. The degree of overlap was based on Langton's (1982) scale: low (0-0.29), medium (0.30-0.59) and high overlap (>0.60).

\section{Statistical analyses}

The null hypothesis of no difference between the TL and TM relationship slopes of males and females was tested after data were $\log _{10}$-transformed with the

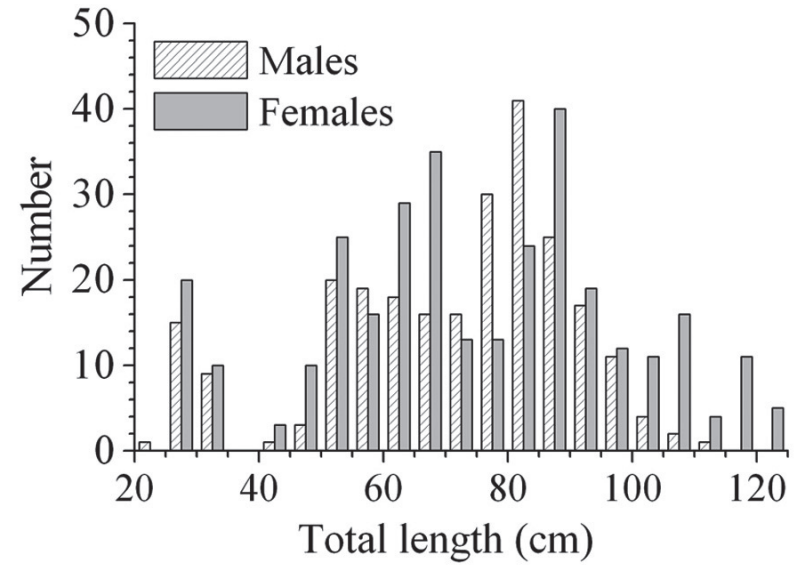

FIG. 2. - Length-frequency distribution for $M$. punctulatus males $(n=249)$ and females $(n=316)$ calculated in $5 \mathrm{~cm}$ length classes.

Student's $t$-test (Zar, 1984). A paired sample $t$-test (Zar, 1984) was used to test for asymmetry between the mass of the right and left testes in males and uteri contents in females. ANOVA followed by a Tukey's post hoc test (Zar, 1984) were used to determine if there were significant differences in the reproductive variables (LFD, GSI and embryo size) by month. The relationship between maternal length and fecundity was compared using ANOVA and linear and non-linear regression (Zar, 1984). The results are presented as a mean \pm confidence interval and the significance level used for the tests was 0.05 .

\section{RESULTS}

\section{Reproductive biology}

\section{Size range and maturity}

Females ranged from 25 to $122 \mathrm{~cm}$ TL (43.75$7920 \mathrm{~g}$ ) and males from 24.5 to $111 \mathrm{~cm}$ TL (39.5$3420 \mathrm{~g}$ ) (Fig. 2). Length-total body mass relationships of females and males were significantly different $(t$-test $=4.365$, d.f $=297, \mathrm{P}<0.05)$. Female and male curves coincide for low TL values, but over $80 \mathrm{~cm}$ TL females were heavier than males at a similar length (Fig. 3).

A plot of clasper length against total fish length produced the typical S-shaped curve (Fig. 4). The elongation of the clasper rose steeply between 70 and $85 \mathrm{~cm}$ TL, which indicates that males mature rapidly in this range. The smallest mature male measured $76 \mathrm{~cm}$ and the largest immature specimen was $88.5 \mathrm{~cm}$ TL. $50 \%$ of males were mature at $81.4 \mathrm{~cm}$ TL (Fig. 5). 


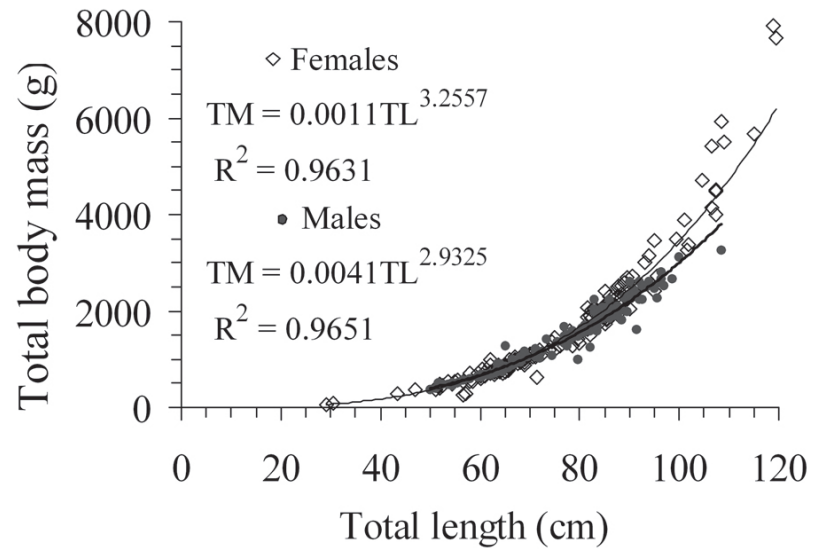

FIG. 3. - Relationship between total body mass and total length in females $(n=140)$ and males $(n=162)$ of $M$. punctulatus from the Gulf of Gabès.

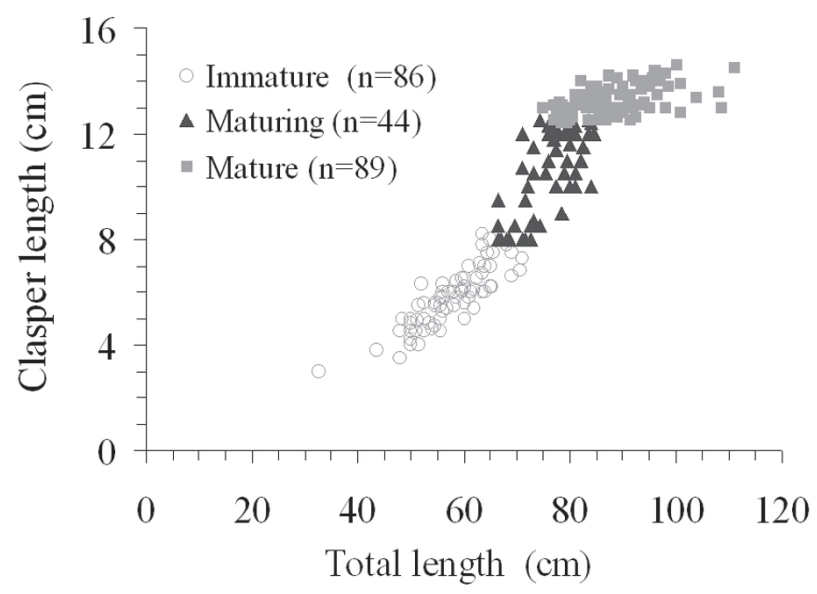

FIG. 4. - Relationship between clasper length and total length for immature, maturing and mature male $M$. punctulatus from the Gulf of Gabès.

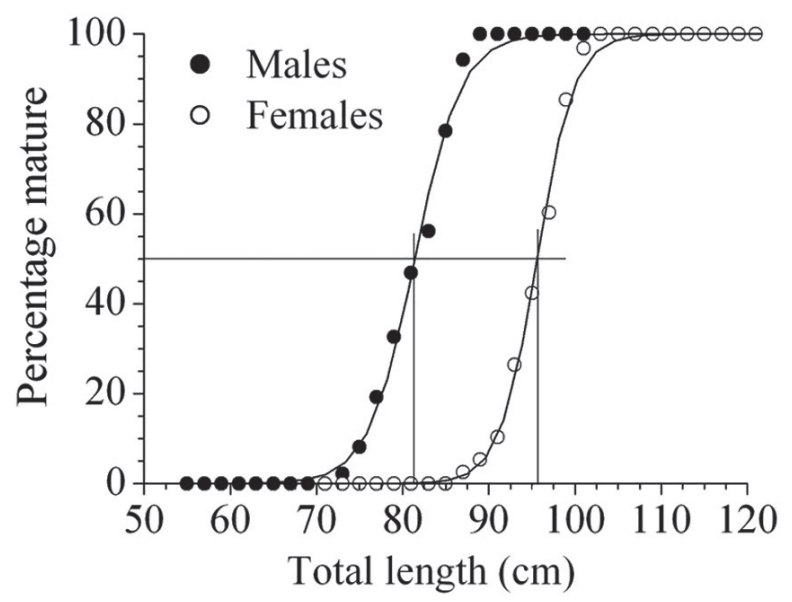

FIG. 5. - Relationship between the percentage of mature Mustelus punctulatus and total length for females and males.

Females with translucent oocytes in the ovary were observed starting from $70 \mathrm{~cm}$. The largest immature female was $100 \mathrm{~cm}$ TL and the smallest mature female was $88 \mathrm{~cm}$ TL. $50 \%$ of females were mature at $95.6 \mathrm{~cm}$ TL (Fig. 5).

\section{Reproductive cycle}

Male M. punctulatus have a symmetrical genital tract with two equally-developed gonads. The masses of the right and left testes were not significantly different in mature males (Paired t-test; $\mathrm{t}=0.438$, $P=0.663$, d. $f=81$ ).

The monthly GSI of mature males was high $(0.98$ to 1.12) between February and April, after which it decreased until it reached a minimum in June-July (0.23-0.26) before increasing steadily in the following months (Fig. 6). Statistical analyses showed that there were no significant changes in GSI between February, March and April, and that the May GSI was significantly different from those of April and June (ANOVA, Tukey's post hoc, $\mathrm{P}<0.05$ ). Furthermore, mature males examined during late May had visibly atrophied testes compared to those collected in April, and their seminal vesicles were very swollen and contained a large amount of semen. This suggests that spermatogenesis begins some time after August and that the spermatozoa produced are accumulated in the seminal vesicle during May in preparation for mating.

The largest follicle diameter (LFD) increased from 5.6 to $6.2 \mathrm{~mm}$ in January and February to approximately $15 \mathrm{~mm}$ in July before declining sharply to the minimum diameter $(3 \mathrm{~mm})$ in August (Fig. 7). Statistical analyses revealed that from February, LFD changed significantly from one month to another and was larger in July (ANOVA, Tukey's post-hoc, $\mathrm{P}<0.05)$. Mean LFD increased subsequently to approximately $5 \mathrm{~mm}$ in December.

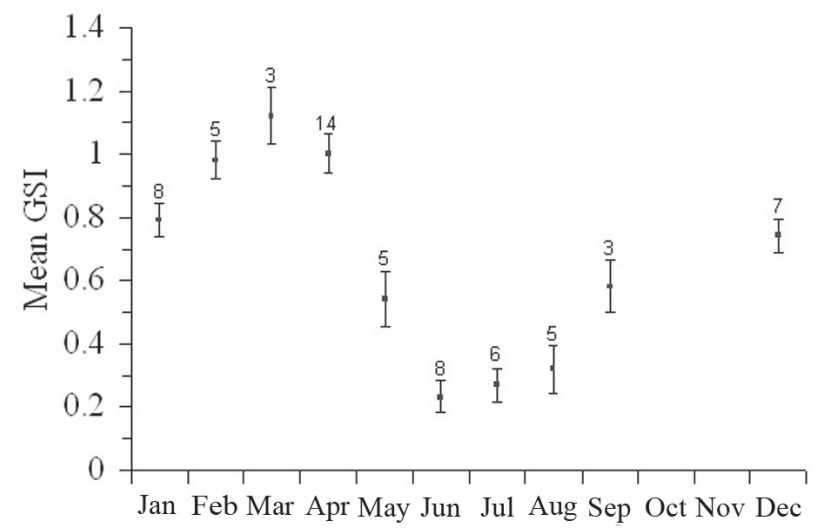

FIG. 6. - Mean monthly gonadosomatic index (GSI) ( $\pm 95 \%$ CI) of mature male Mustelus punctulatus. Sample size is given for each month. 


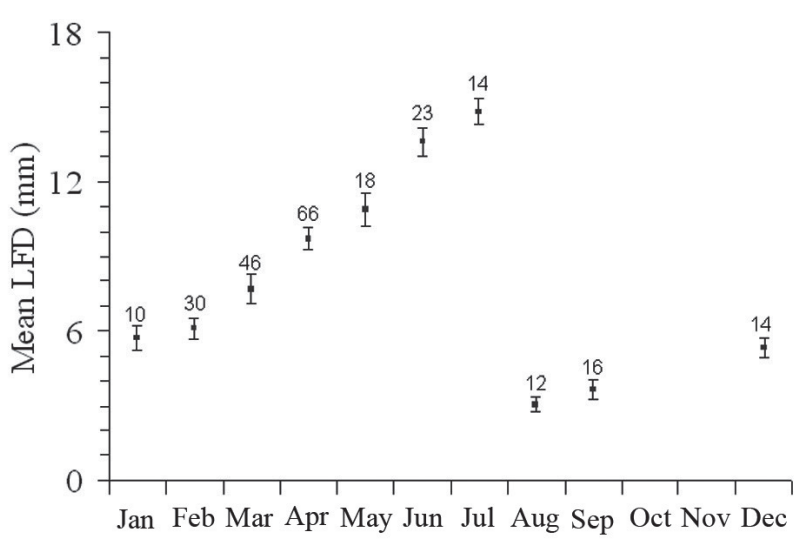

FIG. 7. - Monthly mean largest follicle diameter (LFD) ( $\pm 95 \%$ CI) for female Mustelus punctulatus. Numbers above data points indicate sample sizes.

Therefore, ova development appears to take approximately 12 months.

Mature M. punctulatus females caught from mid-May to early June were either post-partum or pregnant with full-term embryos. Post-partum females had the largest LFD values while females which accomplished ovulation had numerous small previtellogenic follicles accompanied by one to four large atretic ova. Ovulating females were observed from early July to early August while those carrying embryos were caught in September. Embryos increased in size from September (3-4.6 cm TL) to March and May-June (23-30.5cm TL) of the following year (Fig. 8). The embryo lengths in May and early June were significantly larger (ANOVA, Tukey's post-hoc, $\mathrm{P}<0.05)$ than in all other months. Free-swimming neonates were observed by midMay. Thus, ovulation was assumed to occur between early July and early August and parturition to last from mid-May to early June.

\section{Size at birth and fecundity}

Full-term embryos $(n=102)$ examined between 25 April and 4 June, ranged in length from 23 to $30.5 \mathrm{~cm}$ TL $(26.74 \pm 0.38 \mathrm{~cm})$. Moreover, 52 free-swimming specimens that exhibited an unhealed umbilical scar on the ventral surface, which indicates that they were newborn, were observed during June. Their lengths ranged between 24.5 and $32.5 \mathrm{~cm}(28.93 \pm 0.54 \mathrm{~cm})$. The size at birth, therefore, most probably ranged from 24.5 to $30.5 \mathrm{~cm}$ TL.

The number of mature follicles ranged from 14 to $32(20.51 \pm 1.62)$. The relationship between the follicle number (FN) and the TL of the mother can be described by the regression: $\mathrm{FN}=0.327 * \mathrm{TL}-12.62$.

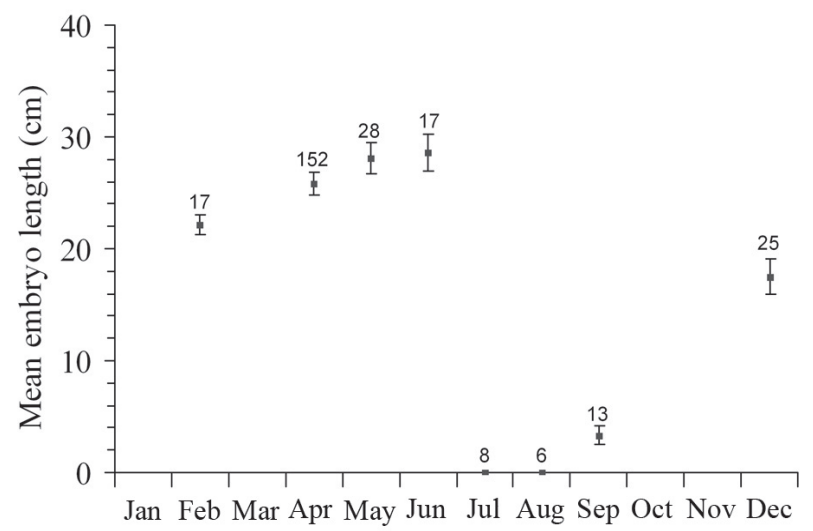

FIG. 8. - Monthly mean embryo length ( $\pm 95 \%$ CI) of Mustelus punctulatus from the Gulf of Gabès. Numbers above data points indicate sample sizes.

A significant linear relationship was found between maternal length and follicle number (ANOVA, $\mathrm{F}_{1,27}$ $\left.=44.785, \mathrm{P}<0.0001, \mathrm{r}^{2}=0.624\right)$.

The number of embryos carried by each female ranged from 12 to $27(18.20 \pm 2.60)$. The relationship between the number of pups $(\mathrm{Np})$ per litter and the TL of the mother can be described by the regression: $\mathrm{Np}=0.542 * \mathrm{TL}-41.55$. The litter size was significantly related to the maternal length (ANOVA, $\mathrm{F}_{1,13}=19.044, \mathrm{P}=0.00076, \mathrm{r}^{2}=0.594$ ).

We counted 192 embryos (98 males and 94 females) in 12 pregnant females. The overall male to female ratio in the sample was 1:1.04, which is not significantly different from a 1:1 sex ratio $\left(\chi^{2}\right.$ $=0.041$, d.f. $=1, P>0.05$ ). On the other hand, there was no significant difference in the mean number of embryos between the left and right uteri (Paired $\mathrm{t}$-test; $\mathrm{t}=1.86, \mathrm{P}=0.089$, d.f $=11$ ). In addition, there was no significant difference between the mean number of sexes in the same uteri (Paired t-test; $\mathrm{t}=$ 0.392, $\mathrm{P}=0.698$, d.f $=23$ ).

\section{Dietary composition}

A total of 133 stomachs was examined, consisting of 67 males (32.5-110 cm TL) and 66 females (30.5$121 \mathrm{~cm} \mathrm{TL}$ ). Of the stomachs sampled, 114 contained food items. Blackspotted smooth-hound sharks consumed a wide range of prey items that belonged to seven major groups: crustaceans, teleosts, molluscs, polychaetes, sipunculids, tunicates and echinoderms (Table 1).

Teleosts had the highest index of relative importance for the main prey items (\%IRI=34.02), and occurred in $48.25 \%$ of stomachs with food. This was followed by crustaceans $(\% \mathrm{IRI}=28.95)$, 
TABLE 1. - Diet composition of Mustelus punctulatus off the Gulf of Gabès $(\% \mathrm{~F}$ : Frequency of occurrence; $\% \mathrm{~N}$ : percentage in number; $\% \mathrm{M}$ : percentage in mass of prey items; \%IRI: percentage index of relative importance.

\begin{tabular}{|c|c|c|c|c|}
\hline & $\% \mathrm{~F}$ & $\% \mathrm{~N}$ & $\% \mathrm{M}$ & $\%$ IRI \\
\hline Crustaceans & 53.51 & 27.22 & 16.23 & 28.95 \\
\hline Shrimps & 22.81 & 9.48 & 9.62 & \\
\hline Sicyonia carinata & 13.16 & 5.81 & 2.06 & 4.54 \\
\hline Parapenaeus longirostris & 1.75 & 0.61 & 0.20 & 0.06 \\
\hline Penaeus kerathurus & 2.63 & 0.92 & 6.83 & 0.89 \\
\hline Shrimps (unid) & 6.14 & 2.14 & 0.54 & 0.72 \\
\hline Crabs & 26.32 & 9.48 & 3.30 & \\
\hline Ethusa mascarone & 2.63 & 0.92 & 0.24 & 0.13 \\
\hline Eucrate crenata & 1.75 & 0.92 & 0.16 & 0.08 \\
\hline Maja squinado & 0.88 & 0.31 & 0.11 & 0.02 \\
\hline Parthenope angulifrons & 1.75 & 0.61 & 0.43 & 0.08 \\
\hline Crabs (unid) & 19.30 & 6.73 & 2.35 & 7.68 \\
\hline Hermit crabs & & & & \\
\hline Paguridae & 4.39 & 2.14 & 0.30 & 0.47 \\
\hline Mantis shrimps & & & & \\
\hline Squilla mantis & 4.38 & 1.53 & 0.68 & 0.43 \\
\hline Unidentified crustaceans & 8.77 & 4.59 & 2.32 & 2.66 \\
\hline Teleosts & 48.25 & 22.63 & 34.00 & 34.02 \\
\hline Sparidae & 6.14 & 5.20 & 11.36 & \\
\hline Diplodus annularis & 2.63 & 2.14 & 5.59 & 0.89 \\
\hline Pagellus erythrinus & 0.88 & 0.31 & 1.01 & 0.05 \\
\hline Spicara sp. & 1.75 & 1.53 & 1.53 & 0.24 \\
\hline Boops boops & 0.88 & 0.31 & 0.40 & 0.03 \\
\hline Sparidae (unid) & 2.63 & 0.92 & 2.83 & 0.43 \\
\hline Clupeidae & 5.26 & 1.83 & 3.55 & \\
\hline Sardina pilchardus & 0.88 & 0.31 & 0.74 & 0.04 \\
\hline Sardinella aurita & 1.75 & 0.61 & 1.39 & 0.15 \\
\hline Clupeidae (unid) & 2.63 & 0.92 & 1.43 & 0.27 \\
\hline Serranidae & 1.75 & 0.61 & 2.79 & \\
\hline Serranus scriba & 0.88 & 0.31 & 0.98 & 0.05 \\
\hline Serranidae (unid) & 0.88 & 0.31 & 1.81 & 0.08 \\
\hline Congridae & 0.88 & 0.92 & 0.40 & \\
\hline Conger conger & 0.88 & 0.92 & 0.40 & 0.05 \\
\hline Carangidae & 3.51 & 1.22 & 6.79 & \\
\hline Caranx sp. & 0.88 & 0.31 & 2.11 & 0.09 \\
\hline Trachurus trachurus & 1.75 & 0.61 & 3.24 & 0.30 \\
\hline Carangidae (unid) & 0.88 & 0.31 & 1.44 & 0.07 \\
\hline Syngnathidae & 1.75 & 0.61 & 0.16 & \\
\hline Hурросатриs hyрросатриs & $s 1.75$ & 0.61 & 0.16 & 0.06 \\
\hline Unidentified teleosts & 32.46 & 12.23 & 8.93 & 30.13 \\
\hline Molluses & 37.72 & 26.30 & 33.70 & 28.18 \\
\hline Cephalopods & 31.58 & 12.23 & 29.71 & \\
\hline Octopus vulgaris & 7.02 & 3.06 & 14.09 & 5.28 \\
\hline Eledone moschata & 2.63 & 1.22 & 0.90 & 0.25 \\
\hline Loligo vulgaris & 3.51 & 1.22 & 5.86 & 1.09 \\
\hline Sepia officinalis & 5.26 & 2.14 & 6.56 & 2.01 \\
\hline Gastropoda (unid) & 7.02 & 14.07 & 3.99 & 5.56 \\
\hline Unidentified molluscs & 13.16 & 4.59 & 2.32 & 3.98 \\
\hline Polychaetes & 18.42 & 7.95 & 5.49 & 3.08 \\
\hline Sipunculids & 23.68 & 10.70 & 6.96 & 5.21 \\
\hline Echinoderms & 3.51 & 1.22 & 0.45 & 0.07 \\
\hline Tunicates & 2.63 & 0.92 & 1.83 & 0.09 \\
\hline Unidentified preys & 7.02 & 3.06 & 1.36 & 0.39 \\
\hline
\end{tabular}

which were frequently the most important prey group $(\%=53.51 \%)$ and were also numerically significant $(\% \mathrm{~N}=27.22 \%)$ (Table 1$)$. The molluscs were the third component of the diet in terms of $\%$ IRI $(28.18 \%)$ and were more important according to mass $(\% \mathrm{M}=33.70)$ than number $(\% \mathrm{~N}=26.30)$. Sipunculids and polychaetes occurred in $23.68 \%$ and $18.42 \%$ respectively of the stomachs with food, and constituted a substantial portion of the diet, while

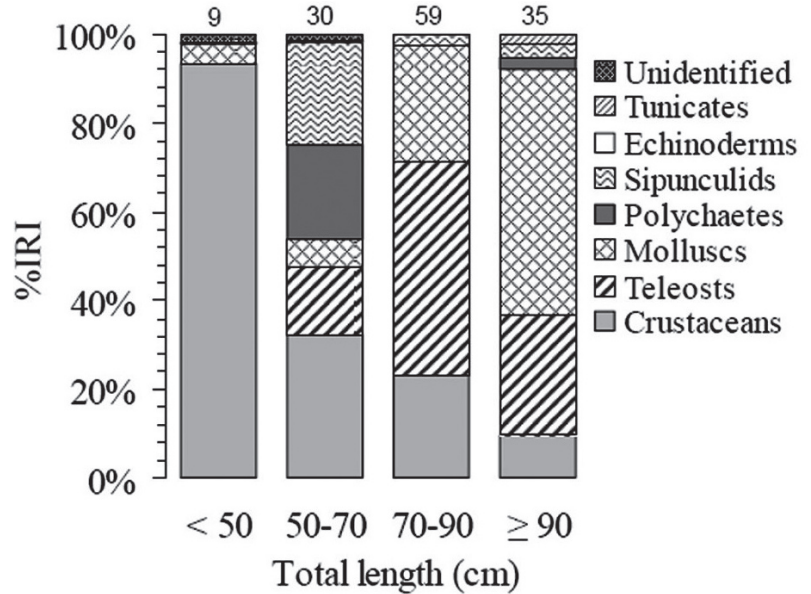

FIG. 9. - Percentage index of relative importance (\%IRI) of the contributions of broad taxonomic groups to the diets of different length classes of Mustelus punctulatus off the Gulf of Gabès. Sample sizes are given above the bar for each length class.

echinoderms and tunicates were minor components.

Among teleosts, the unidentified category was the most numerous (26.30\%) and frequently occurring (32.46\%); the remainder came from 6 families, of which the most common was Sparidae (Table 1). Among crustaceans, unidentified crabs comprised the bulk of items in term of $\% \mathrm{~F}, \% \mathrm{~N}$ and $\% \mathrm{M}$ while, Sicyonia carinata was the most numerous $(\% \mathrm{~N}=13.16)$ as a single prey species. Molluscs comprised cephalopods and gastropods and the former was more important in terms of mass $(\% \mathrm{M}=29.71 \%)$ and frequency of occurrence $(\% \mathrm{~F}=31.58 \%)$. Most cephalopods were quantitatively significant and Octopus vulgaris occurred most plentifully as a single prey species $(\% \mathrm{M}=14.09)$.

Substantial differences in the diet were observed between young, small, medium and large $M$. punctulatus (Fig. 9). Crustaceans decreased and molluscs increased in importance as the blackspotted smooth-hound grew in size. Teleosts increased in importance from small $(\%$ IRI $=15.13)$ to medium $(\%$ IRI $=47.92)$, and then decreased in the large class $(\%$ IRI $=26.83)$ (Fig. 9).

The degree of dietary overlap was low between young and all other size classes $\left(\mathrm{C}_{\mathrm{H}}<0.24\right)$, moderate between small and medium and large $\left(\mathrm{C}_{\mathrm{H}}=0.42\right.$; $0.5)$ and high between medium and large $\left(\mathrm{C}_{\mathrm{H}}=0.75\right)$. The diet of young was more focused on crustaceans $(\%$ IRI $=93.58)$. Although crustaceans were the dominant prey in the small class, polychaetes and sipunculids constituted a substantial part of the diet. In order of importance, sipunculids $(\% \mathrm{IRI}=23.19)$ and polychaetes $(\% \mathrm{IRI}=21.35)$ were the second and third components of the diet of the small class. The 
diet of the medium class was dominated by teleosts $(\%$ IRI $=47.92)$ while molluscs were the dominant prey groups for the large size class $(\% \mathrm{IRI}=55.30)$ (Fig. 9).

\section{DISCUSSION}

\section{Reproductive biology}

Off the Gulf of Gabès, captures of M. punctulatus included newborns, immatures and matures of both sexes. Males and females were found to have different length-total body mass relationships. The female and male curves for this relationship diverge at the onset of maturity, when females begin to grow larger and acquire more body cavity space, muscle and a larger liver in order to produce and accommodate large quantities of reproductive material and young (Klimley, 1987).

Male $M$. punctulatus matured at a smaller size than females did and reached a smaller maximum size, which confirms the sexual dimorphism in sharks (Taniuchi et al., 1993). Sexual dimorphism in maximum size and in size at maturity observed for $M$. punctulatus is common in species of the genus Mustelus (Francis and Mace, 1980; Smale and Compagno, 1997; Yamaguchi et al., 1997; Conrath and Musick, 2002; Oddone et al., 2005; Walker, 2007; Saïdi et al., 2008) and consistent with most species of shark (Lyle, 1987; Stevens and McLoughlin, 1991).

The maximum sizes observed in the present study are considerably smaller than the 182 and $191 \mathrm{~cm}$ TL reported for male and female $M$. mediterraneus respectively off the Gulf of Tunis (Capapé and Quignard, 1977a). Off the Senegalese coasts, the largest male and female $M$. mediterraneus measured 114 and $150 \mathrm{~cm}$ TL respectively (Capapé et al., 1996). Off the Gulf of Tunis, male and female $M$. mediterraneus reached maturity at 90 and 100-120 cm TL respectively (Capapé and Quignard, 1977a). In Senegalese waters, males longer than $83 \mathrm{~cm}$ TL and females longer than $91 \mathrm{~cm}$ TL were mature (Capapé et al., 1996). Geographic variation in size at maturity and maximum size is common in sharks and reflects the plasticity of these traits (Taniuchi et al., 1993; Yamaguchi et al., 2000; Lombardi-Carlson et al., 2003). This suggests that local environmental conditions, latitude, or resilience to fishing, among other factors, could be important in determining maturity and maximum size of sharks (Taniuchi et al., 1993; Yamaguchi et al., 2000; LombardiCarlson et al., 2003). However, the latitudinal difference between this study and the Capapé and Quignard (1977a) study was not considerable. Alternatively, the effect of fishing on M. punctulatus must not be ignored, and given the fishing pressure in the Gulf of Gabès it is conceivable that maximum sizes have decreased since 1977. Nevertheless, neither environmental conditions nor fishing pressure seem to able to explain the differences between the present study and Capapé and Quignard (1997a) and further investigations are needed in order to understand whether the observed geographic variations are the result of phenotypic plasticity, genetic differentiation, fishing pressure or misidentification origin.

Trends in the GSI suggested that the mating season of $M$. punctulatus off the Gulf of Gabès occurred through late May and June. The pattern of the GSI peak in males occurring before ovulation in females observed in $M$. punctulatus has also been observed in other Mustelus species (Teshima, 1981; Conrath and Musick, 2002; Walker, 2007; Saïdi et al., 2008) and other viviparous sharks (Lyle, 1987; Loefer and Sedberry, 2003).

The trend of embryonic growth indicates that the full-term embryos found in May and early June result from the eggs ovulated between early July and early August. However, the maximum embryo lengths coincided with the occurrence of post-partum females, which suggests that parturition occurred from mid-May to early June. Thus, M. punctulatus off the Gulf of Gabès had an annual reproductive cycle with a gestation period of about 11 months. Off the Gulf of Tunis, the gestation period for $M$. mediterraneus was suggested to be 12 months and parturition and ovulation occurred during May and June (Capapé and Quignard, 1977a). In Senegal, the gestation period was suggested to last 12 months and parturition and ovulation occurred during spring and summer (Capapé et al., 1996). The 12 month oocyte development and the 9 to 12 month gestation periods are common in Mustelus species (Francis and Mace, 1980; Capapé, 1983; Lenanton et al., 1990; Smale and Compagno, 1997; Yamaguchi et al., 1997; Conrath and Musick, 2002; Oddone et al., 2005; Walker, 2007; Saïdi et al., 2008). Regional differences in the timing of reproductive events (parturition, ovulation, gestation) might be related to ecological conditions. The occurrence of large follicles in post-partum females indicates that 
vitellogenesis proceeds concurrently with gestation and that females become pregnant shortly after giving birth. Pregnant females caught at the same time all had embryos in the same development stage, which provides further evidence of a short mating and ovulation period. According to the timing of parturition and ovulation, female M. punctulatus off the Gulf of Gabès have a resting period of about one month between pregnancies. It is probable that all Mustelus species have a short resting period between pregnancies (Francis and Mace, 1980).

Ovarian fecundity was higher than uterine fecundity. This is due to the fact that some fullyyolked oocytes did not ovulate and underwent atresia and that some uterine eggs failed to develop. Nondeveloping eggs were also observed in the spotted estuary smooth-hound shark M. lenticulatus (Francis and Mace, 1980), the gummy shark M. antarcticus (Lenanton et al., 1990), and the smooth-hound shark M. mustelus (Smale and Compagno, 1997; Saïdi et al., 2008). Positive correlations between maternal length and fecundities observed in M. punctulatus are common in Mustelus species (Francis and Mace, 1980; Capapé, 1983; Lenanton et al., 1990; Yamaguchi et al., 1997; Conrath and Musick, 2002; Walker, 2007; Saïdi et al., 2008).

The number of pups for the Mustelus species ranges from 1 to 31 (Conrath and Musick, 2002). The blackspotted smooth-hound falls within this range with 12 to 27 pups per litter. In this study, the mean litter size of 18.20 is consistent with the mean litter size of 16.80 reported for $M$. mediterraneus in the Gulf of Tunis (Capapé and Quignard, 1977a) but higher than the range between 3 and 13 along the Senegalese coasts (Capapé et al., 1996).

The sex ratio of 1:1 for embryos observed in the present study is consistent with that reported for M. lenticulatus (Francis and Mace, 1980), M. antarcticus (Walker, 2007) and a number of other viviparous shark species (Lyle, 1987; Watson and Smale, 1998). However, a predominance of male embryos has been reported for M. mediterraneus (Capapé and Quignard, 1977a). The pattern of a 1:1 ratio of embryos between the uteri of $M$. punctulatus is similar to that of M. antarcticus (Walker, 2007), $M$. mustelus (Saïdi et al., 2008) and Triakis semifasciata (Ebert and Ebert, 2005).

Off the Gulf of Gabès, the size at birth for $M$. punctulatus appears to range from 24.5 to 30.5 $\mathrm{cm}$ TL. Size at birth ranged from 40 to $43 \mathrm{~cm}$ off the Gulf of Tunis (Capapé and Quignard, 1977a), and from 42 to $44 \mathrm{~cm}$ on the Senegalese coasts (Capapé et al., 1996). It is difficult to determine whether the differences observed are biological or methodological.

The disparity between the reproductive parameters of M. mediterraneus and M. punctulatus is considerable. However, the reproductive parameters of $M$. mediterraneus seem to resemble $M$. mustelus (Smale and Compagno, 1997; Saïdi et al., 2008). Given the paucity of research into M. punctulatus and the systematic confusion in the genus, a synchronous investigation that samples the Gulf of Gabès and the Gulf of Tunis is necessary to determine whether the observed differences are biological, methodological or originate in systematic confusion. Moreover, further work is required to monitor and sustain the $M$. punctulatus fishery in the Gulf of Gabès. Information on age, growth and mortality of the species would enable demographic studies.

\section{Dietary composition}

The diet of M. punctulatus off the Gulf of Gabès was dominated by benthic and demersal preys, mainly crustaceans, teleosts and molluscs. Polychaetes and sipunculids were each ingested by over $18 \%$ of the individuals and contributed over 5\% to the dietary weight of $M$. punctulatus and were thus a reasonably important component of the diet of this species. The mollusc component of the diet comprised mainly cephalopods. Prey species observed in the stomachs are quite common in the area where $M$. punctulatus specimens were collected, which suggests that this shark is an opportunistic predator that exploits diverse foods.

The diet of $M$. punctulatus conforms to observations reported for other Mustelus species and for the species off the Adriatic Sea (Jardas et al., 2007). However, regional differences were observed among the prey species. Geographic differences in diet have been documented in the sandbar shark $C$. plumbeus (Ellis and Musick, 2007) and starspotted smoothhound Mustelus manazo (Yamaguchi and Taniuchi, 2000). This difference in diet is most probably due to regional habitat use, prey availability and opportunism.

Smooth-hounds of the genus Mustelus mainly ate crustaceans, although molluscs, polychaetes and teleosts may also be important (Smale and Compagno, 1997; Simpfendorfer et al., 2001; Kamura and Hashimoto, 2004). However, the $M$. 
punctulatus sampled had a high proportion of teleosts in their stomachs. An intriguing question is how $M$. punctulatus obtain teleosts: whether they are captured alive or scavenged. The pelagic teleost component of the diet of the Mustelus species appears to be scavenged from fisheries (Smale and Compagno, 1997; Simpfendorfer et al., 2001). However, as in both the Gulf of Gabès and the Adriatic Sea, teleosts constitute a major prey for the species, it may be that this species feeds on teleosts. Nevertheless, further investigation into this link should be conducted.

A comparison of the diet between size classes indicated that $M$. punctulatus exhibited ontogenetic changes in diet, with crustaceans decreasing and molluscs and teleosts increasing in importance with shark size. Capapé and Quignard (1977b) reported similar ontogenetic dietary shifts in M. mediterraneus, with teleosts becoming more important as shark size increased. Changes in dietary composition that accompany growth reflect an increased ability of sharks to consume larger preys such as teleosts and molluscs. These changes could also be related to modifications in the environmental conditions or to the energetic requirements of the animals. In the latter case, diet switching is often associated with optimisation of the energy gained from one or another type of diet (Ebert, 2002). Differences in the diet of M. punctulatus due to size may be the result of different life-history stages using different habitats as a strategy to minimise competition between them. Within the species, reduced competition between adults and young would increase survivorship for the latter during the critical early stages of life.

\section{ACKNOWLEDGEMENTS}

Thanks are expressed to the staff of the INSTM (Institut National des Scineces et Technolohgies de la Mer). We also wish to extend our thanks to $\mathrm{Mr}$ Béjaoui Hafedh who helped proofread this paper and the anonymous reviewers for comments that greatly improved the submitted manuscript.

\section{REFERENCES}

Bradaï, M.N., B. Saïdi, M. Ghorbel, A. Bouaïn, O. Guélorget and C. Capapé. - 2002. Observations sur les requins du golfe de Gabès (Tunisie méridionale, Méditerranée centrale). Mésogée, 60: 61-77.

Capapé, C. - 1983. Nouvelles données sur la biologie de la reproduction de Mustelus asterias Cloquet, 1821 (Pisces, Pleurotremata,
Triakidae) des côtes tunisiennes. Vie Milieu, 33: 143-152.

Capapé, C. and J.P. Quignard. - 1977a. Contribution à la biologie des Triakidae des côtes tunisiennes. I. Mustelus mediterraneus Quignard et Capapé, 1972: répartition géographique et bathymétrique, migration et déplacement, reproduction, fécondité. Bull. Off. Nat. Pêch. Tunisie, 1: 103-122.

Capapé, C. and J.P. Quignard. - 1977b. Contribution à l'étude des Triakidae des côtes tunisiennes. II. Mustelus mediterraneus Quignard et Capapé, 1972: Régime alimentaire. Bull. Off. Nat. Pêch. Tunisie, 1: 173-179.

Capapé, C., M. Diop, M. N'dao and R. Ben Brahim. - 1996. Observations biologiques comparées entre quelques espèces de Sélaciens des côtes tunisiennes (Méditerranée centrale) et de la région de Dakar-Ouakam (Sénégal Atlantique oriental). Ichtyophysiol. Acta, 19: 179-199.

Cavanagh, R.D. and C. Gibson. - 2007. Overview of the Conservation Status of Cartilaginous Fishes (Chondrichthyans) in the Mediterranean Sea. IUCN, Gland (Switzerland) and Malaga (Spain).

Collenot, G. - 1969. Etude biométrique de la croissance relative des ptérygopodes chez la roussette Scyliorhinus canicula L. Cah. Biol. Mar., 10: 309-329.

Compagno, L.J.V. - 1984. FAO species catalogue. Sharks of the world: an annotated and illustrated catalogue of sharks species known to date. Part 2, Carcharhiniformes. FAO Fish. Syn., 125(4): 251-655.

Conrath, C.L. and J.A. Musick. - 2002. Reproductive biology of the smooth dogfish, Mustelus canis, in the northwest Atlantic Ocean. Environ. Biol. Fish., 64: 367-377.

Cortés, E. - 1997. A critical review of methods of studying fish feeding based on analysis of stomach contents: application to elasmobranch fishes. Can. J. Fish. Aquat. Sci., 54: 726-738.

Ebert, D.A. - 2002. Ontogenetic changes in the diet of the sevengill shark (Notorynchus cepediatus). Mar. Freshwater Res., 53: 517-523.

Ebert, D.A. and T.B. Ebert. - 2005. Reproduction, diet and habitat use of leopard sharks, Triakis semifasciata (Girard), in Humboldt Bay, California, USA. Mar. Freshwater Res., 56: 1089-1098.

Ellis, J.K. and J.A. Musick. - 2007. Ontogenetic changes in the diet of the sandbar shark, Carcharhinus plumbeus, in lower Chesapeake Bay and Virginia (USA) coastal waters. Environ. Biol. Fish., 80: 51-67.

Francis, M.P. and J.T. Mace. - 1980. Reproductive biology of Mustelus lenticulatus from Kaikoura and Nelson. New. Zealand. J. Mar. Freshwater Res., 14: 303-311.

Jardas, I., M. Śantić, V. Nerlović and A. Pallaoro. - 2007. Diet composition of blackspotted smooth-hound, Mustelus punctulatus (Risso, 1826), in the eastern Adriatic Sea. J. Appl. Ichthyol., 23: 279-281.

Kamura, S. and H. Hashimoto. -2004 . The food habits of four species of triakid sharks, Triakis scyllium, Hemitriakis japanica, Mustelus griseus and Mustelus manazo, in the central Seto Inland Sea, Japan. Fish. Sci., 70: 1019-1035.

Klimley, A.P. - 1987. The determinants of sexual segregation in the scalloped hammerhead shark, Sphyrna lewini. Environ. Biol. Fish. 18: 27-40.

Krebs, C.J. - 1989. Ecological methodology. Harper Collins, New York

Langton, R.W. - 1982. Diet overlap between Atlantic cod, Gadus morhus, silver hake, Merluccius bilinearis, and fifteen other northwest Atlantic finfish. Fish. Bull., 80: 745-759.

Lenanton, R.C.J., D.I. Heald, M. Platell, M. Cliff and J. Shaw. - 1990. Aspects of the reproductive biology of the gummy shark, Mustelus antarcticus Günther, from waters off the south coast of Western Australia. Aust. J. Mar. Freshwater Res., 41: 807-822.

Loefer, J.K. and G.R. Sedberry. - 2003. Life history of the Atlantic sharpnose shark (Rhizoprionodon terraenovae) (Richardson, 1836) off the southeastern United States. Fish. Bull., 101: 75-88.

Lombardi-Carlson, L.A., E. Cortés, G.R. Parsons and C.A. Manire. - 2003. Latitudinal variation in life-history traits of bonnethead sharks, Sphyrna tiburo, (Carcharhiniformes: Sphyrnidae) from the eastern Gulf of Mexico. Mar. Freshwater Res., 54: 875-883.

Lyle, J.M. - 1987. Observations on the biology of Carcharhinus cautus (Whitley), C. melanopterus (Quoy \& Gaimard) and $C$. 
fitzroyensis (Whitley) from Northern Australia. Aust. J. Mar. Freshwater Res., 38: 701-710.

Oddone, M.C., L. Paesch and W. Norbis. - 2005. Reproductive biology and seasonal distribution of Mustelus schmitti (Elasmobranchii: Triakidae) in the Rio de la Plata oceanic front, south-western Atlantic. J. Mar. Biol. Assoc. UK., 85: 1193-1198.

Pinkas, L., M.S. Oliphant and I.L.K. Iverson. - 1971. Food habits of albacore, bluefi $\mathrm{n}$ tuna and bonito in California waters. Calif. Fish Game, 152: 1-105.

Saïdi, B., M.N. Bradaï and A. Bouaïn. - 2008. Reproductive biology of the smooth-hound shark Mustelus mustelus in the Gulf of Gabès (south-central Mediterranean Sea). J. Fish Biol., 72: 1343-1354.

Serena, F. - 2005. Field identification guide to the sharks and rays of the Mediterranean and Black Sea. FAO, Rome.

Simpfendorfer, C.A., A.B. Goodreid and R.B. McAuley. - 2001. Diet of three commercially important shark species from Western Australian waters. Mar. Freshwater Res., 52: 975-985.

Smale, M.J. and L.J.V. Compagno. - 1997. Life history and diet of two Southern African smoothhound sharks, Mustelus mustelus (Linnaeus, 1758) and Mustelus palumbes Smith, 1957 (Pisces: Triakidae). S. Afr. J. Mar. Sci., 18: 229-248.

Stehmann, M. - 2002. Proposal of a maturity stage scale for oviparous and viviparous cartilaginous fishes (Pisces, Chondrichthyes). Arch. Fish. Mar. Res., 50: 23-48.

Stevens, J.D. and K.J. McLoughlin. - 1991. Distribution, size and sex composition, reproductive biology and diet of sharks from northern Australia. Aust. J. Mar. Freshwater Res., 42: 151-199.
Taniuchi, T., H. Tachikawa, M. Shimizu and Y. Nose. - 1993 Geographical variations in reproductive parameters of shortspine spurdog in the North Pacific. Nippon Suisan Gakkaishi., 59: $45-51$.

Teshima, K. - 1981. Studies on the reproduction of Japanese smooth dogfishes, Mustelus manazo and M. griseus. J. Shimonoseki. Univ. Fish., 29: 113-199.

Walker, T.I. - 2007. Spatial and temporal variation in the reproductive biology of gummy shark Mustelus antarcticus (Chondrichthyes: Triakidae) harvested off southern Australia. Mar. Freshwater Res., 58: 67-97.

Watson, G. and M.J. Smale. - 1998. Reproductive biology of shortnose spiny dogfish, Squalus megalops, from the Agulhas Bank, South Africa. Mar. Freshwater Res., 49: 695-703.

Yamaguchi, A. and T. Taniuchi. - 2000. Food variation and ontogenetic dietary shift of the starspotted-dogfish Mustelus manazo at five locations in japan and Taiwan. Fish. Sci., 66: 1039-1048.

Yamaguchi, A., T. Taniuchi and M. Shimizu. - 1997. Reproductive biology of the starspotted dogfish, Mustelus manazo, from Tokyo Bay, Japan. Fish. Sci., 63: 918-922.

Yamaguchi, A., T. Taniuchi and M. Shimizu. - 2000. Geographic variations in reproductive parameters of the starspotted dogfish, Mustelus manazo, from five localities in Japan and Taiwan. Environ. Biol. Fish., 57: 221-233.

Zar, J.H. - 1984. Biostatistical Analysis, 2nd edn., Prentice-Hall, Englewood Cliffs.

Scient. ed.: E. Massutí.

Received January 29, 2008. September 8, 2008

Published online March 2, 2009. 